\title{
Isolated unilateral vagus nerve palsy secondary to trauma
}

\author{
Travmaya sekonder izole tek taraflı nervus vagus yaralanması
}

\author{
Dursun AYGÜN, ${ }^{1}$ Ethem ACAR ${ }^{2}$
}

\begin{abstract}
A 41-year-old man presented to emergency service with loss of consciousness lasting 20 minutes after a piece of wood struck the right side of his face. Shortly after admission, he developed difficulty swallowing. On admission, he was alert and had normal vital findings. There was no motor, sensorial, or cerebellar deficit. Deviation of the uvula to the left side and pharyngeal reflex loss on the right side was obvious. The right vocal cord was paralyzed. Other cranial nerves were intact on examination. The patient's cranial computed tomography (CT), CT-angiogram, cranial and neck magnetic resonance (MR) imaging, MR-angiogram, and cervical and lung X-ray were normal. We evaluated this case with isolated unilateral vagus nerve palsy (VNP) secondary to trauma at the emergency department. Our case illustrated that trauma can cause isolated VNP with the absence of abnormal findings on imaging modalities.
\end{abstract}

Key Words: Emergency department; isolated vagus nerve palsy; trauma evaluation.
Yüzünün sağ tarafına tahta parçası çarptıktan sonra 20 dakika bilinç kaybı gelişen 41 yaşında erkek hasta acil servise başvurdu. Kabulden kısa bir süre sonra hastada yutma güçlüğü gelişti. Kabülde hasta alertti ve vital bulgular1 normaldi, motor, sensoriyal ve serebeller defisiti yoktu. Uvula sola deviyeydi ve sağ tarafta belirgin farenjeal refleks kaybı vardı. Sağ vokal kortlarda paralizi vardı. Diğer kraniyal sinir muayeneleri intaktı. Hastanın beyin tomografisi (BT), BT anjiyogram1, beyin ve boyun manyetik rezonans (MR) bulguları, MR anjiyogramı, servikal ve akciğer grafileri normaldi. Bu yazıda, acil serviste travmaya bağlı izole tek taraflı nervus vagus yarlanmalı olgu değerlendirildi. Bu olgu görüntüleme tekniklerinde patolojik bulgu olmadan da izole nervus vagus yaralanması olabileceğini göstermektedir.

Anahtar Sözcükler: Acil servis; izole nervus vagus yaralanması; travma değerlendirilmesi.
Vagus nerve palsy (VNP) may be due to trauma, surgery, tumor, internal carotid artery dissection, infection, or inflammation and may be idiopathic. ${ }^{[1-6]}$ Trauma induced VNP is often associated with other cranial nerve involvements (such as IX, XI) and also associated with cranial or facial fractures. ${ }^{[7-8]}$ Urculo et al. ${ }^{[7]}$ reported a case of glossopharyngeal and vagal nerve paralysis following an occipital condyle fracture. Alberio et al. ${ }^{[8]}$ reported a case with isolated glossopharyngeal and vagal nerve palsies due to trauma. However, they established a fracture involving the jugular foramen on cranial computed tomography (CT). It has been reported that in cases with non-traumatic causes of isolated VNP, a lesion may also be established. ${ }^{[1,3,5]}$
Thus, the importance of neuroimaging studies in patients with isolated VNP is clear. In contrast to previous cases, we could not find any associated lesion on imaging modalities although there was a presence of trauma in our case. The patients with trauma have been evaluated firstly at emergency departments. We evaluated a case with isolated unilateral VNP due to trauma and could not find any associated lesion on the patient's imaging modalities.

In this paper, we would like to emphasize that VNP may happen without any associated injury to the neck, skull or brain. VNP should be thought in trauma patients who present with nistagmus and difficulty in swallowing and speaking.

\footnotetext{
${ }^{1}$ Department of Neurology, Ondokuz Mayıs University Faculty of Medicine, Samsun; ${ }^{2}$ Department of Emergency Service, Erzurum Training and Research Hospital, Erzurum, Turkey.
}

${ }^{1}$ Ondokuz Mayıs Üniversitesi Tıp Fakültesi, Nöroloji Anabilim Dalı, Samsun; ${ }^{2}$ Erzurum Bölge Eğitim ve Araştırma Hastanesi, Acil Servis, Erzurum. 


\section{CASE REPORT}

A 41 year old, right handed man presented to emergency service with loss of consciousness. There was no significant disease in the past medical history. It was known that loss of consciousness continued for about 20 minutes and developed after he was struck with a piece of wood on the right side of his face and shortly after admission he developed difficulty in swallowing. On admission, he was alert and had normal vital findings. There was no motor or sensorial deficit. He described vertigo shortly after presentation. Cerebellar tests were normal. However, horizontal nistagmus with rotator component and left beat were observed during vertigo. Deviation of the uvula to left side with pharyngeal reflex loss on the right side were also present. The right vocal cord was paralyzed, with saliva pooling and the rima was 3-4 $\mathrm{mm}$ during phonation. Other cranial nerves were intact on examination. The patient's cranial CT, CT-angiogram, cranial and neck magnetic resonance (MR) imaging, MR-angiogram, and cervical and lung X-ray were all normal. Schemer test was normal in both eyes. The patient was fed entirely via nasogastric tube (NGT) for 10 days due to inability to swallow. He was discharged on the 10th day of admission. Since he could eat semi-solid foods, the NGT was removed after 11 days of discharge. The information from the patient was obtained by telephone after two weeks and showed that his swallowing was gradually getting better. He was able to speak normally (i.e., no voice problem). The present case and previous cases with isolated VNP are shown in Table 1.

\section{DISCUSSION}

Tang et al. ${ }^{[1]}$ reported a case with isolated VNP due to Herpes simplex virus infection. The neck MRI of their case revealed a focal lesion in the sub-glottis region. Nusbaum et al. ${ }^{[3]}$ reported a case with isolated VNP that showed a dissection of the extra cranial internal carotid artery on imaging. Nakagawa et al. ${ }^{[5]}$ reported a case with isolated VNP caused by Varicella zoster virus reactivation, which revealed lesions on the laryngeal mucosa. In the present patient, isolated VNP was due to trauma; however, there was no lesion on the cranial CT, CT-angiogram, cranial and neck MR imaging, MR-angiogram, or cervical and lung Xray of the patient. It has been reported that the majority of isolated unilateral recurrent laryngeal nerve palsies are idiopathic in nature and are associated with diabetes mellitus where palatopharyngeal and articulatory functions are usually normal. ${ }^{[4,8]}$ Our case not only had vocal cord paralysis but also palatopharyngeal involvement. Furthermore, if the lesion is below the origin of the pharyngeal branches, palatal weakness and pharyngeal or palatal sensory loss are also seen. ${ }^{[9]}$ Our case had both palatal weakness and pharyngeal and palatal sensory loss.

In our patient, we think that the vagus nerve damage was located at the exit site of the vagus nerve in the base of skull at the point where it runs into the carotid sheath in the neck. This was reasoned because if the vagus nerve is damaged before emerging from the jugular foramen, the other cranial nerves such as IX, XI, and XII would also be involved at these locations. ${ }^{[2]}$

In the present case, the probable mechanisms of the vagus nerve injury included: (1) excessive rotation and/or lateral flexion of the neck which may cause distraction or stretching of the vagus nerve; and (2) in the upper-cervical area, direct compression to the trunk of the vagus nerve arising from muscular spasm due to trauma or direct trauma to the neck, causing fascicular damage. ${ }^{[2]}$ Due to these mechanisms, trauma may be caused as Sunderland's grade II injury (mild axonotmesis).$^{[10]}$ In this type of injury, complete recovery is more likely than with severe axonotmesis. Our patient could swallow liquid foods and speak normally (i.e., no voice problem) at the 21 st day of admission, followed by swallowing semi-solid foods on the 25 th day of admission. The patient can now more easily swallow solid/semisolid foods. We expect complete recovery of swallowing in the present case.

In conclusion, our case illustrated that trauma can cause isolated VNP with the absence of abnormal findings on imaging modalities. This does not mean that the emergency physician should not evaluate the cases with isolated unilateral VNP at the emergency department, as isolated VNP may be associated with extra cranial internal carotid artery dissection. VNP should be thought of in trauma patients who present with nistagmus and difficulty in swallowing and speaking.

Conflict-of-interest issues regarding the authorship or article: None declared.

Table 1. Previous reports with isolated vagal nerve palsy with present case

\begin{tabular}{llll}
\hline References & Case (Years / Sex) & Etiology & Lesion localization \\
\hline Nusbaum et al. ${ }^{[3]}$ & $40 /$ Male & Trauma & ICA dissection \\
Tang et al. ${ }^{[1]}$ & $29 /$ Male & HSV-infection & The sub-glottis region \\
Nakagawa et al. ${ }^{[5]}$ & $55 /$ Female & VZV-infection & The larynx mucosa \\
The present case & $41 /$ Male & Trauma & No associated lesion \\
\hline
\end{tabular}

ICA: Internal carotid artery; HSV: Herpes simplex virus; VZV: Varicella-zoster virus. 


\section{REFERENCES}

1. Tang SC, Jeng JS, Liu HM, Yip PK. Isolated vagus nerve palsy probably associated with herpes simplex virus infection. Acta Neurol Scand 2001;104:174-7.

2. Brazis PW, Masdeu JC, Biller J. Localization in clinical neurology. 3rd ed. Boston: Little, Brown \& Co.; 1996.

3. Nusbaum AO, Som PM, Dubois P, Silvers AR. Isolated vagal nerve palsy associated with a dissection of the extracranial internal carotid artery. AJNR Am J Neuroradiol 1998;19:18457.

4. Berry $\mathrm{H}, \mathrm{Blair}$ RL. Isolated vagus nerve palsy and vagal mononeuritis. Arch Otolaryngol 1980;106:333-8.

5. Nakagawa H, Satoh M, Kusuyama T, Fukuda H, Ogawa K. Isolated vagus nerve paralysis caused by varicella zoster virus reactivation. Otolaryngol Head Neck Surg 2005;133:460-1.

6. Vaile $\mathrm{JH}$, Davis P. Isolated unilateral vagus nerve palsy in systemic lupus erythematosus. J Rheumatol 1998;25:2287-8.

7. Urculo E, Arrazola M, Arrazola M Jr, Riu I, Moyua A. Delayed glossopharyngeal and vagus nerve paralysis following occipital condyle fracture. Case report. J Neurosurg 1996;84:522-5.

8. Alberio N, Cultrera F, Antonelli V, Servadei F. Isolated glossopharyngeal and vagus nerves palsy due to fracture involving the left jugular foramen. Acta Neurochir (Wien) 2005;147:791-4.

9. Victor M, Ropper AH. Diseases of the cranial nerves. In: Victor M, Ropper AH, editors. Adams and Victor's principles of neurology. 7th ed. New York: McGraw-Hill; 2001. p. 144663.

10. Murray B. Peripheral nerve trauma. In: Bradley, WG, Daroff RB, Fenichel GM, Jankovic J, editors. Neurology in clinical practice. Philadelphia: Butterworth \& Heinemann; 2004. p. $1179-95$. 